\title{
Effect of Abamectin on the Cereal Cyst Nematode (CCN, Heterodera avenae) and Wheat Yield
}

Dianli Zhang, Key Laboratory of Pesticide Toxicology \& Application Technique, College of Plant Protection, Shandong Agricultural University, Tai' an, Shandong 271018, P. R. China; Hongyan Wang, Key Laboratory of Pesticide Toxicology \& Application Technique, College of Plant Protection, Shandong Agricultural University, Tai'an, Shandong 271018, P. R. China; and Cotton Research Center, Shandong Academy of Agricultural Sciences, Jinan, Shandong 250100, P. R. China; Xiaoxue Ji and Kaiyun Wang, Key Laboratory of Pesticide Toxicology \& Application Technique, College of Plant Protection, Shandong Agricultural University, Tai' an, Shandong 271018, P. R. China; Dong Wang, College of Agronomy, Shandong Agricultural University, State Key Laboratory of Crop Biology, Key Laboratory of Crop Ecophysiology and Farming System, Ministry of Agriculture, Tai' an, Shandong 271018, P. R. China; and Kang Qiao, Key Laboratory of Pesticide Toxicology \& Application Technique, College of Plant Protection, Shandong Agricultural University, Tai' an, Shandong 271018, P. R. China

\begin{abstract}
The cereal cyst nematode (CCN, Heterodera avenae) is a major pest in wheat and until now there is no pesticide registered to control this pest in China. Development of effective methods of controlling CCN is urgently needed. Abamectin is a biological pesticide that has a high nematicide activity. However, the efficacy of abamectin soil application to control $\mathrm{CCN}$ in wheat and its effect on yield in China remains unknown. Therefore, laboratory, greenhouse, and field tests were carried out to evaluate the potential of abamectin soil applications for $\mathrm{CCN}$ control and improvement

of wheat yield. Laboratory tests showed that abamectin exhibited knockdown toxicity to $\mathrm{CCN}$, with $\mathrm{LC}_{50}$ and $\mathrm{LC}_{90}$ values 9.8 and $59.4 \mathrm{mg} \mathrm{liter}^{-1}$. Greenhouse experiment and field trials showed that soil applications of abamectin provided significant $\mathrm{CCN}$ control and higher straw dry weights and wheat grain yields. There was an 8.5 to $19.3 \%$ yield increase from the various abamectin treatments compared with the control. The results of this study demonstrated that abamectin exhibited a high nematicidal activity to $H$. avenae and adequate performance to enhance wheat crop yields.
\end{abstract}

Plant-parasitic nematodes are economically important pests, causing significant damage in many crop species, resulting in production reduction of about $\$ 157$ billion annually (Abad et al. 2008). Cereal cyst nematode (CCN, Heterodera avenae) is one of the most important nematode species attacking wheat crops (Peng et al. 2015). In China, $\mathrm{CCN}$ was first reported in 1989 and has now been found in more than 16 provinces (Peng et al. 2009). Furthermore, over 4,000,000 ha of the primary wheat growing areas in China were infested by $\mathrm{CCN}$, and yield losses reached $40 \%$ in some heavily infested wheat production areas (Peng et al. 2015; Wu et al. 2014).

Control of CCN depends on the use of resistant cultivars and application of chemical pesticides (Dababat et al. 2015). However, current agronomic practices are not effective enough and breeding resistant varieties of wheat is a long term strategy. Thus, $\mathrm{CCN}$ control in wheat fields still largely depends on chemical methods. In China, the situation of pesticides usage is very complicated. Many chemical nematicides are not available to growers because they are expensive and might endanger the ecosystem (Ibekwe 2004; Zasada et al. 2010). On the other hand, high toxic pesticides like aldicarb, methomyl, or cadusafos are under strict restriction. Therefore, there is an urgent need to develop novel and environmentally friendly $\mathrm{CCN}$ control methods.

Over the last few decades, the Chinese government gave great importance to the development of biological pesticides. Furthermore, to reduce the use of pesticides, last year, China initiated the 2020 Zero-Growth Action Plan for Pesticides that emphasizes the role of green pest prevention and control (MOA 2015). Biological pesticides are often considered the substitutes for chemical pesticide (Glare et al. 2012; Ratnadass et al. 2012). Many attempts have been tried to use biological pesticides to control CCN (Zhang et al. 2014b; 2016). Zhang et al. (2014a) reported that Trichoderma longibrachiatum could control $\mathrm{CCN}$ by inducing enzyme-triggered resistance and promoting competitive plant growth.

Corresponding authors: Dong Wang, E-mail: wangd@sdau.edu.cn; Kang Qiao, E-mail: qiaokang11-11@163.com

Accepted for publication 9 February 2017.

(C) 2017 The American Phytopathological Society
Abamectin is a macrocyclic lactone derived from the actinobacterium Streptomyces avermitilis, which can be applied through spray treatment or soil application (Cabrera et al. 2013). In China, the toxicity grading of abamectin is depends upon its formulation, not the abamectin technical product, which is highly toxic. Abamectin degrades easily in the ecosystem and the active ingredient concentration of abamectin formulations is very low.

Abamectin is a biological pesticide that has high nematicidal activity to control many important plant parasitic nematodes in multiple crops (Cabrera et al. 2013). Previous field studies demonstrated that infurrow application of $0.22 \mathrm{~kg}$ abamectin $\mathrm{ha}^{-1}$ effectively reduced damage by the southern root-knot nematode on tomato in China (Qiao et al. 2012, 2014). Oka et al. (2009) reported similar results from the application of $0.4 \mathrm{~kg}$ abamectin $\mathrm{ha}^{-1}$ as a seed treatment for $\mathrm{CCN}$-infested soils in pot tests but a much lower level of efficacy in field trials with spring wheat in Israel. However, the efficacy of abamectin soil application to control $\mathrm{CCN}$ in wheat and its effect on yield in China remains unknown.

Therefore, the main objectives of the present study were (i) to determine the toxicity of abamectin to $\mathrm{CCN}$, and (ii) to evaluate the biological potential of abamectin soil applications to control $\mathrm{CCN}$ and improvement of wheat yield in greenhouse and field trials.

\section{Materials and Methods}

Chemicals. Technical abamectin (95\% pure, Rainbow, Shandong, China) and formulated abamectin $(0.5 \% \mathrm{G}$, active ingredient, ai, Shibang, Shandong, China) were used in this study.

Nematode inoculum preparation. Soil samples were obtained in Tai'an (Shandong, China) from a Taishan 24 wheat field that had a high density of $H$. avenae. The CCN cysts were collected by a modified Fenwick flotation can method (Caswell et al. 1985; Fenwick, 1940). The isolated $H$. avenae cysts were immersed in $1 \%$ sodium hypochlorite $(\mathrm{NaOCl})$ for $2 \mathrm{~min}$, and rinsed in tap water to remove $\mathrm{NaOCl}$. Then the cysts were incubated in sterile water for 8 to 10 weeks at $4^{\circ} \mathrm{C}$ and 4 weeks at $16^{\circ} \mathrm{C}$. After that, second-stage juveniles (J2s) hatching in the first 2 days were abandoned, then $\mathrm{J} 2$ s collected after $24 \mathrm{~h}$ were used and adjusted to $500 / \mathrm{ml}$ in tap water. Experiments were carried out in an incubator (SPX-400I-G, Boxun Industry \& Commerce Co., Ltd, P. R. China) with temperature of $16 \pm 1{ }^{\circ} \mathrm{C}$ and $60 \%$ relative humidity. 
Laboratory test. The effect of abamectin to control $\mathrm{CCN}$ was ascertained in aqueous tests. Abamectin solutions of 200, 100, 50, 20, 10, and $2 \mathrm{mg}$ ai liter $^{-1}$ were prepared in acetone + water (2\%:98\%). A $0.5 \mathrm{ml}$ aliquot of solution and $\mathrm{J} 2 \mathrm{~s}$ of $\mathrm{CCN}$ were added to every well of a 24-well plate, containing about $250 \mathrm{~J} 2 \mathrm{~s}$ per well. The same volume of acetone + water was used as a control. Well plates wrapped with Parafilm were placed in plastic zip-lock bags. Units were kept at $16^{\circ} \mathrm{C}$. After $24 \mathrm{~h}$ incubation, dead $\mathrm{J} 2$ numbers were recorded by observing movement when exposing them to $4 \%(w / v) ~ \mathrm{NaOH}$ solution for 3 min (Chen and Dickson 2000). The test was replicated six times and repeated three times. Schneider-Orelli's formula was used to calculate $\mathrm{J} 2$ adjusted mortality: \% mortality adjusted $=100 \times([\%$ mortality treated - mortality control]/[100 - mortality control] $)$ (Schneider-Orelli 1947). Then lethal concentrations (LC) required to kill $50 \%\left(\mathrm{LC}_{50}\right)$ and 90\% ( $\left.\mathrm{LC}_{90}\right)$ of $\mathrm{J} 2 \mathrm{~s}$ were determined by logit/probit dose response/ mortality regression (SPSS, V17, IBM SPSS Statistics, Chicago, IL).

Greenhouse and field tests. The highly nematode-susceptible wheat Taishan 24, provided by the Tai' an Academy of Agricultural Sciences, was used in both greenhouse and field tests.

Pot tests, using $15 \mathrm{~cm}$ square flower pots, were conducted in a greenhouse. Cinnamon soil with organic matter content $10.3 \mathrm{~g} \mathrm{~kg}^{-1}$ soil, and $\mathrm{pH}$ 5.7, was collected from heavily $\mathrm{CCN}$-infested wheat fields in Feicheng, Tai' an, China $\left(35.5802^{\circ} \mathrm{N}, 116.6375^{\circ} \mathrm{E}\right)$ and used in pot tests. Cinnamon soil is a silt loam, composed of $32.5 \%$ sand, $65.1 \%$ silt, and $2.4 \%$ clay. Cinnamon soil is a primary soil type at the field trial location, accounting for $14.7 \%$ of total arable land in Shandong Province. The CCN-infested field soil was adjusted with sterilized cinnamon soil to produce an inoculum mix with a density of 20 cysts/100 g soil. Each pot had $300 \mathrm{~g}$ of the $\mathrm{CCN}$ inoculum mix and five wheat seeds added. Abamectin formulated product $(0.5 \% \mathrm{G})$ was applied at 15,30 , and $45 \mathrm{~kg} \mathrm{ha}^{-1}\left(0.075,0.15\right.$, and $0.225 \mathrm{~kg}$ ai ha $\left.{ }^{-1}\right)$, and mixed with CCN inoculum before it was placed into the pots. Soil applied with equal water was served as untreated control. The pots were watered every 3 days and placed at 16 to $20^{\circ} \mathrm{C}$, a $16: 8 \mathrm{~h}$ light/dark photoperiod, and $75 \% \mathrm{RH}$. Three months later, the whole plants and the soil in the pots were rinsed with tap water in a $300 \mu \mathrm{m}$ sieve. Then the numbers of white females remaining on the root systems and retained on the sieves were counted by stereo microscope (Olympus, China). The relative control efficacy was calculated using the following formula:

$$
\text { Relative control efficacy }(\%)=(\mathrm{CK}-\mathrm{PT}) / \mathrm{CK} \times 100 \%
$$

where CK is white female numbers per plant in the control, and PT represents the number of white females per plant/treatment. The tests were replicated six times and repeated three times.

Two field experiments were conducted in Feicheng, Tai' an (15.6 CCN cysts per $100 \mathrm{~g}$ soil initially), in 2014 and 2015. Seeds were sown on 6 October 2014 and 28 September 2015. Three days before sowing, the selected site was fertilized using $200 \mathrm{~kg} \mathrm{ha}^{-1}$ urea and $400 \mathrm{~kg} \mathrm{ha}^{-1}$ ammonium bicarbonate. The plots were $1.5 \times 8.0 \mathrm{~m}$ with 16 rows and arranged in a randomized complete block design with four replicates. The plants and row spacing were 15 and $20 \mathrm{~cm}$, respectively. Treatments were abamectin $(0.5 \% \mathrm{G})$ furrow applied at a rate of 45,30 , and $15 \mathrm{~kg} \mathrm{ha}^{-1}$ and an untreated control. Abamectin was just furrow applied to planting rows at a depth of $20 \mathrm{~cm}$ rather than the whole plots to achieve high local concentration. After that, a notillage planter was used to sow at a rate of $180 \mathrm{~kg} \mathrm{ha}^{-1}$. Plots were hand weeded and irrigated when needed. At grain filling stage, 20 wheat plants and the soil around the roots from three points in each plot were dug up with a scoop. The number of white females on each plant was recorded as described in the greenhouse tests. Wheat plant straw dry weight and grain yield were measured at harvest time to evaluate the effects of abamectin on wheat growth.

Data analysis. Prior to analysis, data expressed as percentages were arcsine transformed to homogenize variances. Sources of variation were treatments and blocks. The effects of different chemical treatments were examined using analysis of variance (ANOVA) and when the $F$-test was significant at $P<0.05$, treatment means were compared using the Student-Newman-Keuls test (SPSS, V17, IBM SPSS Statistics, Chicago, IL). The field data were analyzed for homogeneity of variances. When the variance was equal across years, the pooled data of both tests were combined.

\section{Results}

Laboratory test. Abamectin at all concentrations showed a significant lethal effect on the $\mathrm{J} 2 \mathrm{~s}$ of $H$. avenae, and the increased concentrations of abamectin increased the inhibitory effect. In contrast, the control had little inhibitory effect on J2s (Fig. 1). The $\mathrm{LC}_{50}$ and $\mathrm{LC}_{90}$ of abamectin were 9.8 and $59.4 \mathrm{mg}$ ai liter ${ }^{-1}$, respectively (after $24 \mathrm{~h}$ ).

Greenhouse tests. For the greenhouse tests, in the untreated control, the number of white females per plant was 80.8 . Compared with

Table 1. Effect of abamectin on control of Heterodera avenae in a greenhouse

\begin{tabular}{lccc}
\hline Chemicals & Rates & $\begin{array}{c}\text { White } \\
\text { females/plant }\end{array}$ & $\begin{array}{c}\text { Reduced numbers of } \\
\text { white females compared } \\
\text { with control (\%) }\end{array}$ \\
\hline Abamectin & $45 \mathrm{~kg} \mathrm{ha}^{-1}$ & $18.8 \pm 1.4 \mathrm{c}$ & 76.7 \\
Abamectin & $30 \mathrm{~kg} \mathrm{ha}^{-1}$ & $21.5 \pm 2.3 \mathrm{c}$ & 73.4 \\
Abamectin & $15 \mathrm{~kg} \mathrm{ha}^{-1}$ & $27.8 \pm 4.8 \mathrm{~b}$ & 65.6 \\
Control & - & $80.8 \pm 2.7 \mathrm{a}$ & - \\
\hline
\end{tabular}

${ }^{\mathrm{z}}$ Means followed by the same letter in columns are not significantly different by least significant difference test at $P=0.05$.

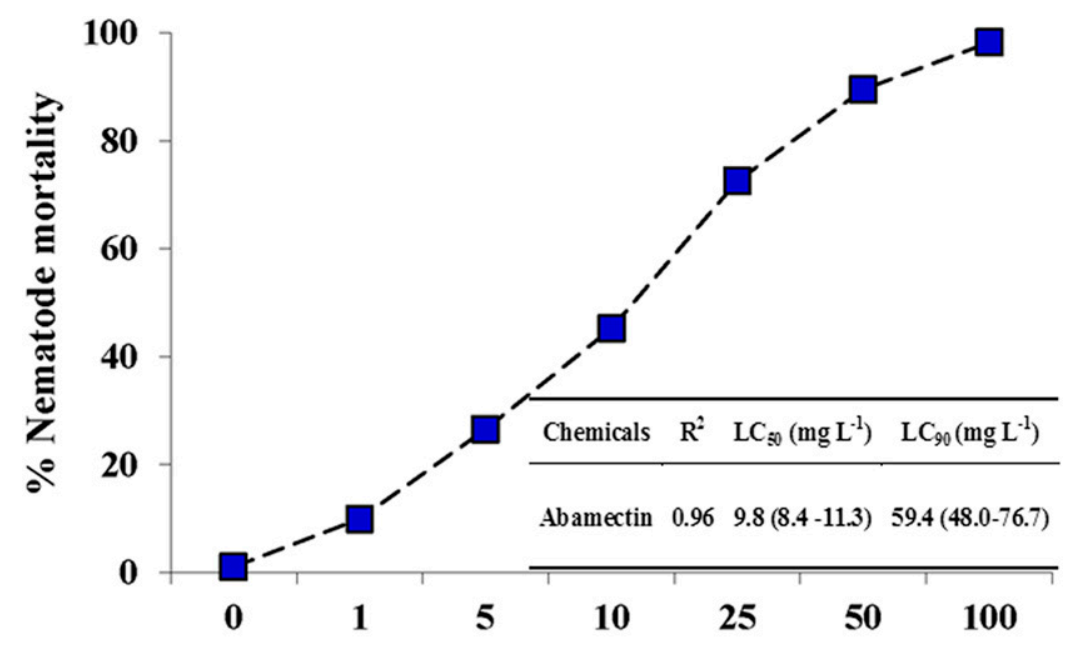

Concentration $\left(\mathrm{mg} \mathrm{L}^{-1}\right)$

Fig. 1. Nematode mortality $(\%)$ and lethal concentrations $\left(\mathrm{LC}_{50}\right.$ and $\left.\mathrm{LC} \mathrm{C}_{90}\right)\left(\mathrm{mg}\right.$ liter $\left.{ }^{-1}\right)$ of abamectin against Heterodera avenae juveniles $(\mathrm{J} 2 \mathrm{~s})$ when incubated for $24 \mathrm{~h}$ at $16^{\circ} \mathrm{C}$. 
this control, the abamectin treatments with dose rates of 45,30 , and $15 \mathrm{~kg} \mathrm{ha}^{-1}$ reduced white female counts by $76.7 \%$ (18.8 white females/plant), $73.4 \%$ (21.5 white females/plant), and $65.6 \%$ (27.8 white females/plant), respectively (Table 1 ).

Field tests. For the field tests, in the untreated control, the number of white females per plant was 62.2. Compared with the control, the abamectin treatments with dose rates of 45,30 , and $15 \mathrm{~kg} \mathrm{ha}^{-1}$ reduced white female counts by $65.4 \%$ ( 21.5 white females/plant), $61.9 \%$ (23.7 white females/plant), and 46.9\% (33.0 white females/ plant), respectively (Table 2).

The application of abamectin significantly increased straw dry weight (Fig. 2A), with a plateau effect occurring at the $30 \mathrm{~kg} \mathrm{ha}^{-1} \mathrm{ap}-$ plication rate. All abamectin treatments also increased the wheat yields compared with control. There was an 8.5 to $19.3 \%$ yield increase from the increasing abamectin treatment rates, as compared

Table 2. Effect of abamectin on control of Heterodera avenae in the field

\begin{tabular}{lccc}
\hline Chemicals & Rates & $\begin{array}{c}\text { White } \\
\text { females/plant }\end{array}$ & $\begin{array}{c}\text { Reduced numbers of } \\
\text { white females compared } \\
\text { with control (\%) }\end{array}$ \\
\hline Abamectin & $45 \mathrm{~kg} \mathrm{ha}^{-1}$ & $21.5 \pm 1.8 \mathrm{c}$ & 65.4 \\
Abamectin & $30 \mathrm{~kg} \mathrm{ha}^{-1}$ & $23.7 \pm 1.7 \mathrm{c}$ & 61.9 \\
Abamectin & $15 \mathrm{~kg} \mathrm{ha}^{-1}$ & $33.0 \pm 5.1 \mathrm{~b}$ & 46.9 \\
Control & - & $62.2 \pm 2.1 \mathrm{a}$ & -
\end{tabular}

${ }^{\mathrm{z}}$ Means followed by the same letter in columns are not significantly different by least significant difference test at $P=0.05$. with the control (Fig. 2B). The highest yield of wheat was achieved in the abamectin at the rate of $45 \mathrm{~kg} \mathrm{ha}^{-1}$.

\section{Discussion}

Overall, the laboratory assays indicated that abamectin has some lethal effect on CCN. Application of abamectin was previously shown to cause irreversible paralysis in root-knot nematodes and increasing concentrations increased mortality (Faske and Starr 2006).

As a short half-life pesticide that is immobile in soil, there is some doubt whether abamectin in soil could kill juveniles inside the cyst. Juveniles may recover from abamectin toxicity under laboratory conditions; however, they are probably too weak to infect a host root and would likely die of starvation in the field. In the present greenhouse and field tests, the different concentrations of abamectin had significant impacts against $\mathrm{CCN}$, and thus, abamectin can be considered as a potential biological nematicide. The results agreed with Cabrera et al. (2009), who reported that using abamectin as a seed treatment on maize, cotton, and sugar beet was an efficient way to reduce early nematode attack of Pratylenchus zeae, Meloidogyne incognita, and H. schachtii.

Oka et al. (2009) reported that abamectin increased root length and reduced the number of CCNs in an inoculated study, but a much lower level of efficacy was observed in field trials with spring wheat. Similar field results showed that application of $0.04 \mathrm{~kg}$ abamectin $\mathrm{ha}^{-1}$ had negligible effects on spring wheat grain yield and postharvest density of CCN in the U.S.A. (Smiley et al. 2012). This inconsistency of results probably resulted from many different factors such as soil type, sampling time, and environmental conditions in different countries.
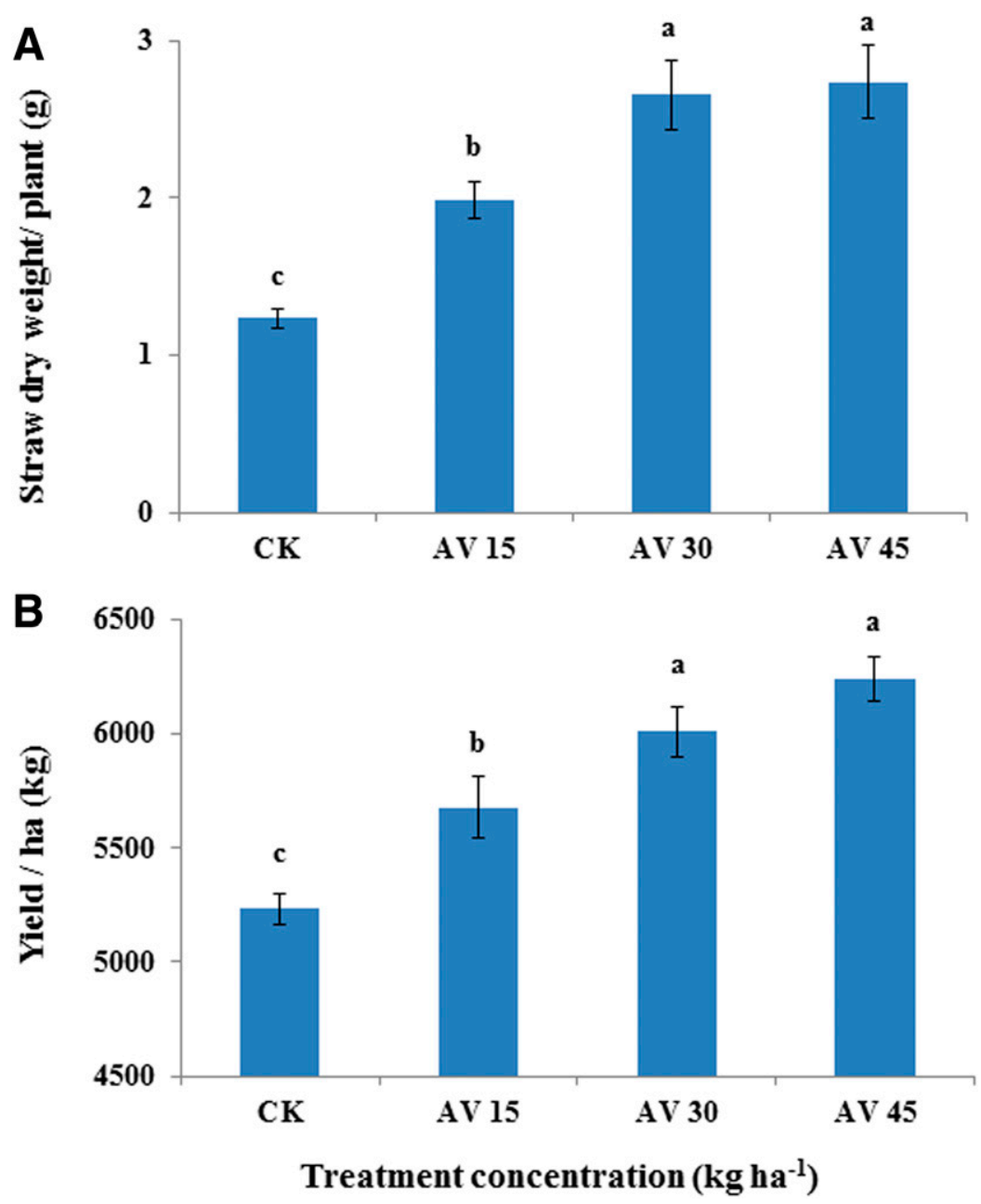

Fig. 2. Influence of abamectin (AV) on wheat plant growth during two years of testing in soils naturally infested with Heterodera avenae. The bars correspond to the standard error. Bars with different letters are significantly different $(P=0.05)$. A, Influence of abamectin on straw dry weight; $\mathbf{B}$, influence of abamectin on grain yield. 
Also, our studies involved placement of abamectin in the root zone below the seed, whereas the study in the U.S.A. involved coating seeds with abamectin. Seed-applied abamectin is unlikely to move down into the root zone where these nematodes invade differentiating tissues at the root tips.

Greenhouse and field test results showed that all the abamectin rates increased the crop yield compared with the untreated control. A positive relationship existed between abamectin rates and wheat yield. Furthermore, the moderate rate, $30 \mathrm{~kg} \mathrm{ha}^{-1}$, provided the best increase in yield and was not statistically different from the maximum rate of abamectin. The cost of abamectin is about $500 \mathrm{RMB} \mathrm{ha}^{-1}$. The yield increase was about $750 \mathrm{~kg} \mathrm{ha}^{-1}$. The market price of wheat is about 1.5 $\mathrm{RMB} \mathrm{kg}^{-1}$, so using abamectin could increase income of farmers by more than $600 \mathrm{RMB} \mathrm{ha}^{-1}$ (approximately US\$90 ha-1). Therefore, abamectin applied to soil as described in this study at the rate of $30 \mathrm{~kg}$ $\mathrm{ha}^{-1}$ would be recommended to maximize profits in $\mathrm{CCN}$-infested fields in China.

For successful management of $\mathrm{CCN}$, the population density at which abamectin should be applied must be identified. Studies have been conducted to determine the relationship between population densities of CCN and yield losses in wheat. Li et al. (2015) reported that the yield loss of wheat increased with increasing density of CCN. Wheat yield loss was more than $77 \%$ when the initial population of $\mathrm{CCN}$ was 465 eggs and J2s/g soil. Another study showed that control measures should be implemented in wheat fields when the initial CCN population was higher than $8 \mathrm{eggs} / \mathrm{ml}$ soil (Liang et al. 2014). For making economic threshold recommendations, other factors like soil texture and type, and CCN tolerance rating of the cultivars should also be considered. Additional research examining the combined impact of these factors on abamectin efficacy is needed.

In conclusion, the results of the study demonstrated that abamectin showed high nematicidal activity on $H$. avenae and adequate performance to enhance wheat crop yield. Soil applications of abamectin would be one solution to manage $\mathrm{CCN}$ in heavily infested wheat production areas. However, further studies need to be conducted with this nematicide to prolong its effective duration and identify the optimal dosage to improve performance of abamectin in the wheat crop.

\section{Acknowledgments}

This research was supported by the National Natural Science Foundation of China (31601661) and the Special Fund for Agro-scientific Research in the Public Interest (201503130).

\section{Literature Cited}

Abad, P., Gouzy, J., Aury, J. M., Castagnone-Sereno, P., Danchin, E. G. J., Deleury, E., Perfus-Barbeoch, L., Anthouard, V., Artiguenave, F., and Blok, V. C. 2008. Genome sequence of the metazoan plant-parasitic nematode Meloidogyne incognita. Nat. Biotechnol. 26:909-915.

Cabrera, J., Kiewnick, S., Grimm, C., Dababat, A., and Sikora, R. 2009. Efficacy of abamectin seed treatment on Pratylenchus zeae, Meloidogyne incognita and Heterodera schachtii. J. Plant Dis. Prot. 116:124-128.

Cabrera, J., Menjivar, R., Dababat, A., and Sikora, R. 2013. Properties and nematicide performance of avermectins. J. Phytopathol. 161:65-69.

Caswell, E. P., Thomason, I. J., and McKinney, H. E. 1985. Extraction of cysts and eggs of Heterodera schachtii from soil with an assessment of extraction efficiency. J. Nematol. 17:337-340.

Chen, S. Y., and Dickson, D. W. 2000. A technique for determining live secondstage juveniles of Heterodera glycines. J. Nematol. 32:117.
Dababat, A., Imren, M., Erginbas-Orakci, G., Ashrafi, S., Yavuzaslanoglu, E. Toktay, H., Pariyar, S., Elekcioglu, H., Morgounov, A., and Mekete, M. 2015. The importance and management strategies of cereal cyst nematodes, Heterodera spp., in Turkey. Euphytica 202:173-188.

Faske, T. R., and Starr, J. L. 2006. Sensitivity of Meloidogyne incongita and Rotylenchulus reniformis to abamectin. J. Nematol. 38:240-244.

Fenwick, D. W. 1940. Methods for the recovery and counting of cysts of Heterodera schachtii from soil. J. Helminthol. 18:155-172.

Glare, T., Caradus, J., Gelernter, W., Jackson, T., Keyhani, N., Kohl, J., Marrone, P., Morin, L., and Stewart, A. 2012. Have biopesticides come of age? Trends Biotechnol. 30:250-258.

Ibekwe, A. M. 2004. Effects of fumigants on non-target organisms in soils. Adv. Agron. 83:1-35.

Li, X., Gao, B., Wang, R., Ma, J., and Chen, S. 2015. Relationships between population densities of the cereal cyst nematode, Heterodera avenae, and yield losses of winter wheat in Hebei Province. Acta Phytophylac. Sin. 42 124-129.

Liang, X., Zhang, L., Guan, Y., Hu, X., Wang, X., and Li, H. 2014. Effects of initial population density of Heterodera avenae on nematode reproduction and wheat growth and yield. J. Triticeae Crops 34:1136-1140.

MOA. 2015. 2020 Chemical fertilizer use and pesticide use zero-growth action plans. Online: http://www.moa.gov.cn/zwllm/tzgg/tz/201503/t20150318_4444765. htm.

Oka, Y., Gözel, U., Spiegel, Y., and Mor, M. 2009. Cereal cyst nematodes in Israel, and their biology and control strategies. Pages 118-123 in: Cereal Cyst Nematodes: Status, Research and Outlook. I. T. Riley, J. M. Nicol, and A. A. Dababat, eds. CIMMYT, Ankara, Turkey.

Peng, D., Nicol, J., Li, H., Hou, S., Li, H., Chen, S., Ma, P., Li, H., and Riley, I 2009. Current knowledge of cereal cyst nematode (Heterodera avenae) on wheat in China. Pages 29-34 in: Cereal Cyst Nematodes: Status, Research and Outlook. I. T. Riley, J. M. Nicol, and A. A. Dababat, eds. CIMMYT, Ankara, Turkey.

Peng, D., Peng, H., and Huang, W. 2015. Occurrence, distribution and integrated management of the cereal cyst nematodes (Heterodera avenae \& H. filipjevi) in China. Pages 17-24 in: Nematodes of Small Grain Cereals: Current Status and Research. A. A. Dababat, H. Muminjanov, and R. W. Smiley, eds. FAO, Ankara, Turkey.

Qiao, K., Duan, H., Wang, H., Wang, Y., Wang, K., and Wei, M. 2014. The efficacy of the reduced rates of 1.3-D+abamectin for control of Meloidogyne incognita in tomato production in China. Sci. Hortic. (Amsterdam) 178:248 252

Qiao, K., Liu, X., Wang, H. Y., Xia, X. M., Ji, X. X., and Wang, K. Y. 2012. Effect of abamectin on root-knot nematodes and tomato yield. Pest Manag. Sci. 68:853-857.

Ratnadass, A., Fernandes, P., Avelino, J., and Habib, R. 2012. Plant species diversity for sustainable management of crop pests and diseases in agroecosystems: a review. Agron. Sustain. Dev. 32:273-303.

Schneider-Orelli, O. 1947. Entomologisches Praktikum. HR Sauerlander, Aarau, Switzerland.

Smiley, R. W., Gourlie, J. A., Rhinhart, K. E. L., Marshall, J. M., Anderson, M. D. and Yan, G. 2012. Influence of nematicides and fungicides on spring wheat in fields infested with soilborne pathogens. Plant Dis. 96:1537-1547.

Wu, H., He, Q., Liu, J., Luo, J., and Peng, D. 2014. Occurrence and development of the cereal cyst nematode (Heterodera avenae) in Shandong, China. Plant Dis. 98:1654-1660.

Zasada, I. A., Halbrendt, J. M., Kokalis-Burelle, N., LaMondia, J., McKenry, M. V., and Noling, J. W. 2010. Managing nematodes without methyl bromide. Annu. Rev. Phytopathol. 48:311-328.

Zhang, J., Li, Y., Yuan, H., Sun, B., and Li, H. 2016. Biological control of the cereal cyst nematode (Heterodera filipjevi) by Achromobacter xylosoxidans isolate 09×01 and Bacillus cereus isolate 09B18. Biol. Control 92:1-6.

Zhang, S., Gan, Y., and Xu, B. 2014a. Efficacy of Trichoderma longibrachiatum in the control of Heterodera avenae. BioControl 59:319-331.

Zhang, S., Gan, Y., Xu, B., and Xue, Y. 2014b. The parasitic and lethal effects of Trichoderma longibrachiatum against Heterodera avenae. Biol. Control 72:1-8. 